\title{
Criterion for tool wear limitation on blanking 18-8 stainless steel strips ${ }^{(\bullet)}$
}

\author{
F. Faura ${ }^{(*)}$, J. López ${ }^{(*)}$ y J. Sanes ${ }^{(*)}$
}

\begin{abstract}
The present article shows a wear limiting criterion for 18-8 stainless steel punching process. For this reason, different factors such as length of the tool, clearance or materials, have been considered in order to obtain the number of possible strokes between grindings and the total number of blanks until a complete total failure. Finally, the maximum number of possible strokes which it will give the economically accepted wear can be obtained. The results obtained by the present method are in good agreement with the previous experimental and theoretical work. Blanking tests were performed using a $20 \mathrm{t}$ press at a speed of 150 strokes/min. The punching material used in these tests was AISI A2 with diameters between 6 and $14 \mathrm{~mm}$. The blanking tests were performed at a clearance between 5 and $20 \%$ of the thickness of the work material.
\end{abstract}

Keywords: Tool wear. Tool life. Blanking. Stainless steel.

\section{Criterio para la limitación del desgaste de herramientas en el punzonado de chapa de acero inoxidable 18-8}

\begin{abstract}
Resumen El presente artículo desarrolla un criterio para la limitación del desgaste en procesos de punzonado de chapa de acero inoxidable 18-8. Se han considerado diferentes factores, tales como longitud de la herramienta, juego de corte o materiales, para establecer dicho criterio. El objetivo final es determinar el máximo número de operaciones entre dos reacondicionados consecutivos de la herramienta hasta el completo deterioro de la misma. En consecuencia, se ha obtenido el máximo número posible de operaciones que puede realizarse en unas condiciones de trabajo determinadas para llegar a un desgaste económicamente aceptable. Los resultados obtenidos por el presente método tienen una excelente correspondencia con estudios teóricos y experimentales previos. Los ensayos fueron realizados utilizando una prensa de $20 \mathrm{t}$ y una velocidad de 150 golpes/min para juegos de corte comprendidos entre un 5 y $20 \%$ del espesor de la chapa. El material del punzón usado en los ensayos fue un AISI A2 con diámetros comprendidos entre 6 y $14 \mathrm{~mm}$.
\end{abstract}

Palabras clave: Desgaste de herramienta. Vida de herramienta. Punzonado. Acero inoxidable.

\section{INTRODUCTION}

As the material for the fabrication of various sheet metal parts of business machines, electric appliances, measuring equipment and instruments, 18-8 stainless steel and bainite hardened steel, have excellent qualities, such as mechanical strength, rigidity, hardness, wear resistance and anticorrosion properties. But, these materials are very difficult to shear and form because of their rather extreme hardness and strength they wear the press-working tools greatly, especially the blanking tools.

$(\bullet$ Trabajo recibido el día 22 de noviembre de 1996

(*) Dpto. de Ingeniería de Materiales y Fabricación. E.T.S Ingenieros Industriales. Universidad de Murcia. Alfonso XIII, 34. 30203-Cartagena. Murcia (España). e-mail:faura@plc.um.es
Therefore, it is very important to find out the means to decrease the tool wear. For this purpose, the tool wear mechanism must be first clarified. But, the blanking tools wear mechanism is very complex owing to many factors affecting the wear in addition to the complexity of the shearing phenomenon. So, studies on the blanking tool wear are scarce.

The early origins of blanking research focused on tool wear problems and tool life formulations. Research on punch wear started in Germany during the 50's (1-2).

Later on, in 1963 the first work by Buchmann (3) about wear and its influence on the blanking of steel sheet was published. This work can be considered as the starting point of the current studies on these phenomena, in which the measure of punch and die face flank, and edge wear were 
considered for the first time, evaluating them by using very similar technics to those used at present.

This last guideline was used in different works (4). More recently they are also relevant to the works of Zivanovic (5).

In Japan, these studies started later than in Germany, being Prof. Maeda who did the first contribution.

In 1971, Maeda and Aoki (6) developed their first studies on complex materials punching such as stainless steels and bainite hardened steels. These results helped to clarify the various mechanisms of tool wear for the different materials and even to elucidate the major existing differences between flank and face punch wear.

More recently (7) studies about the micromechanism of wear have been developed.

Other relevant further aportations, in some cases with a metallurgical character (8-9), are those made by a wear measuring system different from the one previously mentioned.

The wear of a blanking tool has great effects not only on the dimensional accuracy of products but also on working efficiency and economy.

Generally, the acceptable tool wear is an user decision taking into account criteria such as minimum cost, maximum quality, etc.

A possible wear limiting criterion is the one which maximizes the tool life. From this point of view, there will be a maximum wear for which the highest number of strokes is possible during the tool life (total number of strokes until complete failure).

The present study refers to the following working conditions: 18-8 stainless steel (sheet material); $1 \mathrm{~mm}$ (sheet thickness) and circular blanking. These restrictions are not so limiting if we consider that circular blanking is by far the most commonly used and that the amount of stainless steel represents an important percentage of the total amount of materials used in sheet-forming processes.

Generally, in punching, the total worn area can be expressed as the addition of three terms: punch flank wear, punch face wear and cutting edge wear. In the case of blanking of 18-8 stainless steel the flank wear is much larger than the face wear, being the cutting edge wear negligible. In this study, the shape of wear on punching flank has been modeled through a simple geometry.

\section{PLANNING}

\subsection{Equipment used in blanking tests}

In order to check certain hypothesis, it has performed many tests. Blanking tests were performed using a $20 \mathrm{t}$ press at a speed of 150 strokes/min, punching stainless steel (sheet material) of $1 \mathrm{~mm}$ of thickness and $20 \mathrm{~mm}$ of width.

Figure 1 shows a scheme of the punching equipment. It can see the tools of the process -punch and die- with their respective holders, and also, the feeding direction of work material. For this purpose, an automated feeding-evacuation system that ensures an advance speed of approximataly $30 \mathrm{~mm} / \mathrm{s}$ was used.

\subsection{Experimental procedure}

It is possible to evaluate tool wear in punching processes, calculating the eliminated area in several sections of the punch and quantifing, after that, the mean value (6). Therefore, wear can be expressed

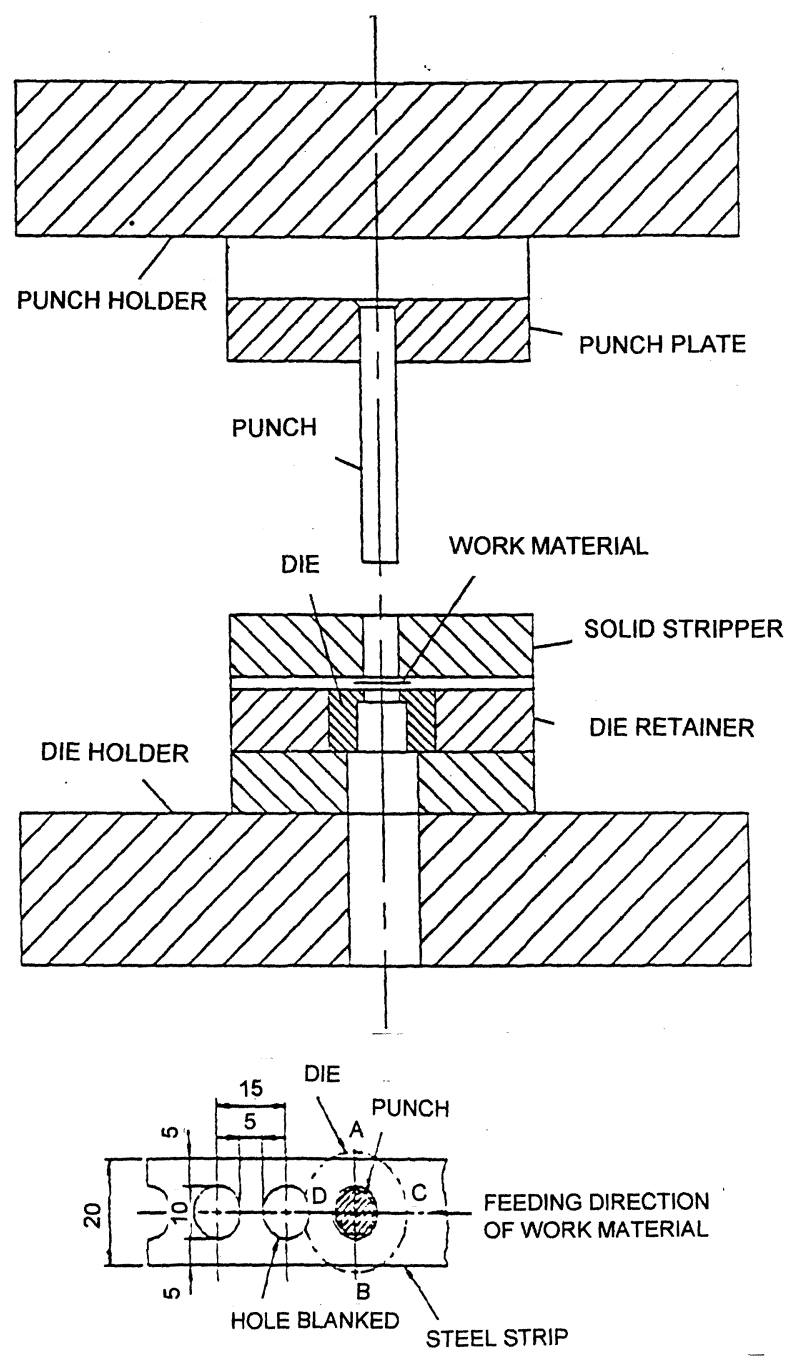

FIG. 1.- Press and blank layout for the measuring of tool wear.

FIG. 1.- Disposición del equipo de ensayos para la medida del desgaste de la herramienta. 
in area units, generally in $\mu \mathrm{m}^{2}$. The total worn area, $S_{\mathrm{p}}\left(\mu \mathrm{m}^{2}\right)$ can be expressed as the addition of three terms (Fig. 2):

$$
S_{\mathrm{p}}=S_{1}+S_{2}+S^{\prime}
$$

The most representative factor for the tool life is clearance from many points of view and perhaps it is the only one susceptible to be varied in the planning of the manufacturing process. Therefore, clearance will be considered as the fundamental parameter of the study that is going to be carried out (Fig. 3).

AISI 304 stainless steel has a punch flank wear, $S_{1}$, much larger than $S_{2}$, being $S^{\prime}$ negligible. Figure 4 shows the shape of wear of punch flank with the number of parts blanked under $10 \%$ clearance (10).

As it can be deduced from the previous experimental results (6 and 10), it seems reasonable to suppose that the face punch wear is constant when the number of strokes is higher than 15,000.

Thus, the worn shape is approximately triangular; therefore on measuring the values $a$ and $b$ in figure 5, total worn area will be approximately equal to the supposed triangular surface.

$$
S_{\mathrm{p}}=\frac{b \times a}{2}
$$

In order to establish the wear limitation criterion, this hypothesis of value a approximately constant will be checked.

Having in mind that the blanking tests were performed using a $20 \mathrm{t}$ press working at a speed of 150 strokes/min. Series of 40,000 strokes for each diameter and clearance have been developed.

On the other hand, the tool wear has been evaluated, calculating the worn area in several sections of the punch each 5,000 strokes, since the

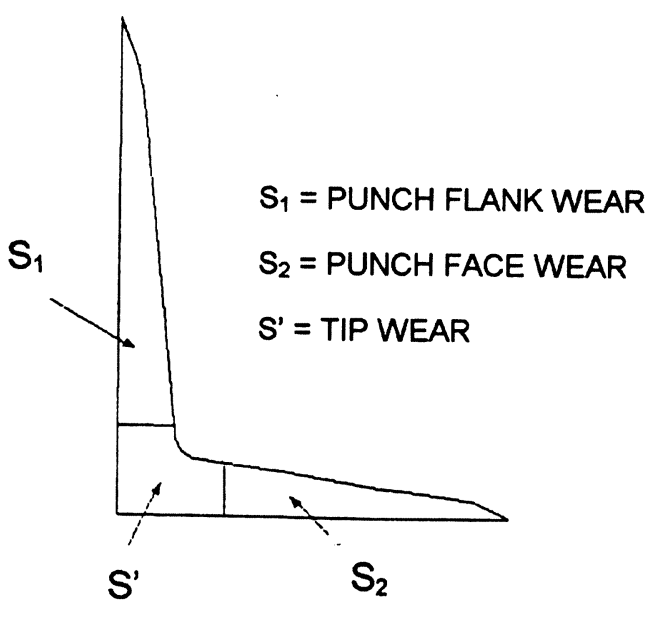

FIG. 2.- Total worn area.

FIG. 2.-Area total desgastada.

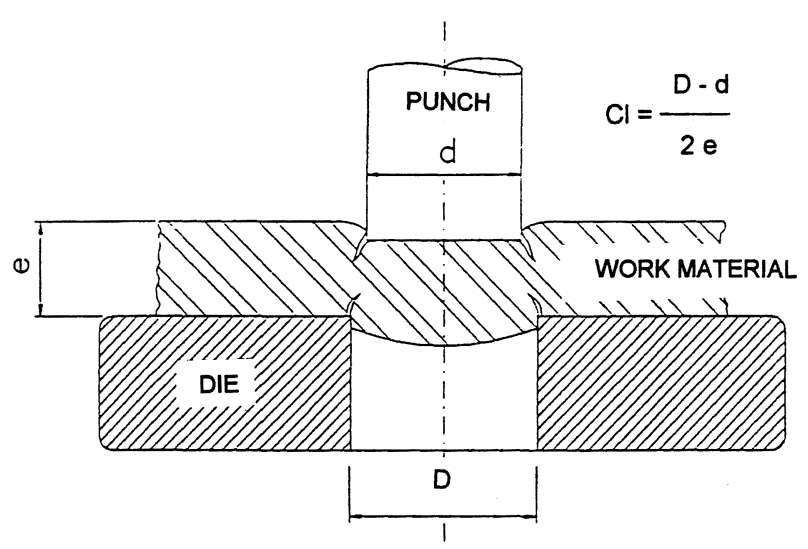

FIG. 3.- Definition of clearance.

FIG. 3.-Definición del juego de corte.

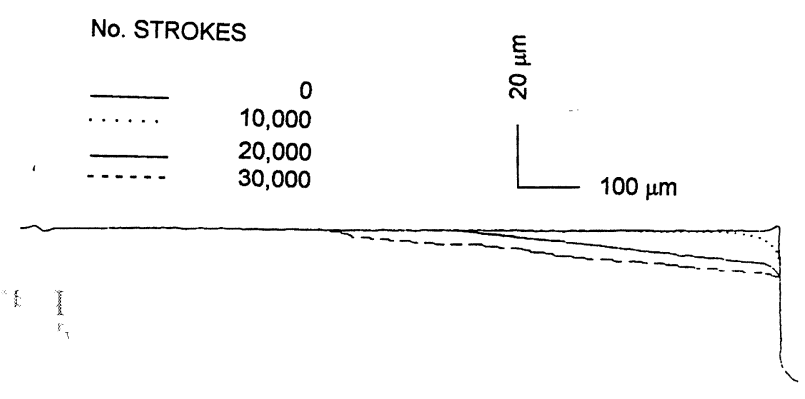

FIG. 4.- Shape of wear on punch flank.

FIG. 4._Forma del desgaste en el flanco del punzón.

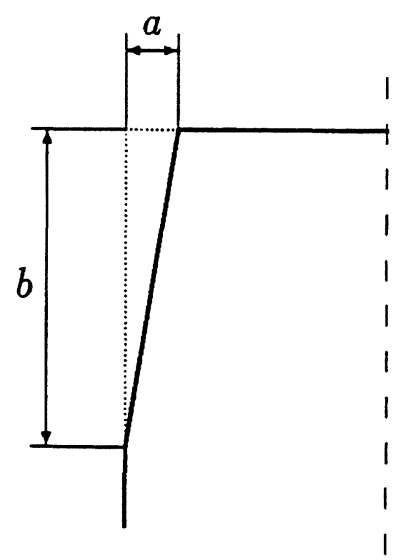

FIG. 5.- Triangular section of the worn area.

FIG. 5.- Sección triangular del área desgastada.

uniform wear did not occur on the periphery of the cutting edge. Therefore, the amounts and shapes of wear were measured at the four normal positions (Fig. 6) -points of measuring in tool- to the feeding direction of the work material and parallel with a vertical projection equipment with optical resolution $\times 60$. Once the values were obtained the 


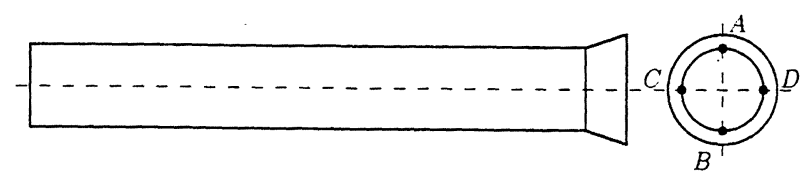

FIG. 6.- Points of measuring in tool.

FIG. 6.- Puntos de medida en la herramienta.

worn areas were calculated in the four sections $\left(S_{\mathrm{pA}}, S_{\mathrm{pB}}, S_{\mathrm{pC}}, S_{\mathrm{pD}}\right)$. The tool wear is calculated as a mean of the previous values.

$$
S_{\mathrm{pm}}=\frac{S_{\mathrm{pA}}+S_{\mathrm{pB}}+S_{\mathrm{pC}}+S_{\mathrm{pD}}}{4}
$$

As it is shown in table I, tests were performed for diameters of $6,8,10,12$ and $14 \mathrm{~mm}$ with clearances of $5,8,11,14$ and $17 \%$ of the thickness of the work material. Therefore, it has made approximately 200 series of 5,000 strokes each.

It has used a clearance of $5 \%$ as the lowest value because it has been demostrated that for lower clearance values, undesirable effects appear such as cracks, chipping, cold welding, etc., which can interrupt the forming process.

In figure 7 (number of strokes versus wear) it can see some results (Table II) for 6 and $8 \mathrm{~mm}$ diameters.

Figures $8 a$ ) and b) represent the evolution of the magnitude $a$ with the number of strokes for 6 and 8 $\mathrm{mm}$ punch diameters respectively. When the wear stabilizes (from 25,000 strokes), the magnitude $a$ is

TABLE I.- Number of tests

TABLA I.- Número de ensayos

\begin{tabular}{|c|c|c|c|c|c|}
\hline Strokes & \multicolumn{5}{|c|}{ Diameters } \\
\hline & 6 & 8 & 10 & 12 & 14 \\
\hline $\begin{array}{l}\text { From } \\
5,000\end{array}$ & $\begin{array}{rr}5 & 8 \\
11 & 14 \\
17 & \end{array}$ & $\bullet \bullet \bullet$ & $\bullet \bullet \bullet$ & $\bullet \bullet \bullet$ & $\bullet \bullet \bullet$ \\
\hline 10,000 & : & & & & • \\
\hline $\begin{array}{l}\bullet \\
\bullet \\
\bullet \\
\bullet \\
\bullet\end{array}$ & $\begin{array}{l}\bullet \\
\bullet \\
\bullet \\
\bullet \\
\bullet\end{array}$ & & & & $\begin{array}{l}\bullet \\
\bullet \\
\bullet \\
\bullet \\
\bullet\end{array}$ \\
\hline To 40,000 & $\bullet \bullet \bullet$ & $\bullet \bullet$ & $\bullet \bullet \bullet$ & ๑०॰ & $\bullet \bullet \bullet$ \\
\hline
\end{tabular}

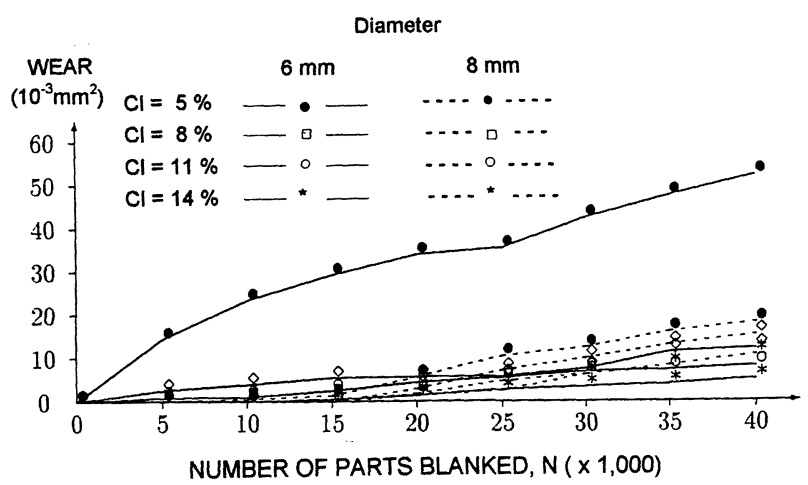

FIG. 7.- Number of strokers versus wear.

FIG. 7.-Número de golpes frente al desgaste.

approximately constant, taking a mean value of $0.02 \mathrm{~mm}$. This value confirms this hypothesis.

\section{CRITERIA OF WEAR LIMITATION}

As it has been already mentioned, acceptable tool wear (11) is an user's decision taking into account criteria such as minimum costs, maximum quality, etc.

A possible wear limiting criterion is the one which maximizes the tool life. From this point of view, there will be a maximum wear for which the highest number of strokes is possible during tool life (total number of strokes until complete failure). This value could be calculated continuing a reasoning similar to the one that is carried out in the case of the processes of metal cutting (machining). The method used for the calculation of the economically possible wear in blanking of 18-8 stainless steel, $1 \mathrm{~mm}$ (sheet thickness) and circular blanking (AISI A2) are describing below.

The worn area can be represented by a triangular section as shown in figure 9. It has been demostrated that the value $a$ is also a constant for different clearances. In this case, and according to the obtained results, $a$ is approximately $20 \mu \mathrm{m}$

The value $b$ can be obtained by the equation [2].

$$
b=\frac{2 S_{\mathrm{p}}}{a}
$$

On the other hand, if $A$ is the length of the tool, the number of possible grindings will be:

$$
n=\frac{A}{b}
$$

where $b$ is the length lost in each grinding and can be calculated as follows: 
TABLE II.- Wear from results of tests

TABLA II. - Valores del desgaste obtenidos de los ensayos

\begin{tabular}{|c|c|c|c|c|c|c|c|c|c|c|c|}
\hline \multirow{3}{*}{$\begin{array}{c}\text { No. } \\
\text { strokes } \\
\times 1,000\end{array}$} & \multicolumn{11}{|c|}{ Clearance, $\mathrm{Cl}$} \\
\hline & \multicolumn{2}{|c|}{$\begin{array}{c}0.05 \\
\text { diameter }\end{array}$} & \multicolumn{2}{|c|}{$\begin{array}{c}0.08 \\
\text { diameter }\end{array}$} & \multicolumn{2}{|c|}{$\begin{array}{c}0.11 \\
\text { diameter }\end{array}$} & \multicolumn{3}{|c|}{$\begin{array}{c}0.14 \\
\text { diameter }\end{array}$} & \multicolumn{2}{|c|}{$\begin{array}{c}0.17 \\
\text { diameter }\end{array}$} \\
\hline & 6 & 8 & 6 & 8 & 6 & 8 & 6 & 8 & 10 & 14 & 10 \\
\hline 5 & 14.442 & - & 2.499 & - & 0.8075 & - & - & - & - & - & - \\
\hline 10 & 23.490 & 0.5750 & 4.020 & - & 1.0770 & - & - & - & - & - & - \\
\hline 15 & 29.463 & 1.4375 & 5.603 & - & 2.5477 & - & 0.5747 & - & - & - & - \\
\hline 20 & 34.093 & 5.7200 & 5.817 & 3.0175 & 4.4602 & 1.8875 & 1.4865 & 1.5275 & - & 1.1200 & - \\
\hline 25 & 35.716 & 10.618 & 5.817 & 7.2500 & 5.6030 & 4.8175 & 2.8350 & 2.5450 & - & 3.7250 & 0.8825 \\
\hline 30 & 42.638 & 12.620 & 7.632 & 10.138 & 6.9795 & 6.3900 & 3.5073 & 6.3675 & 3.5750 & 5.8100 & 1.7133 \\
\hline 35 & 47.690 & 16.152 & 11.466 & 13.183 & 7.3613 & & 4.1665 & 8.3825 & 5.2360 & 8.0325 & 1.7903 \\
\hline 40 & 52.456 & 18.268 & 12.314 & 15.420 & 8.2467 & & 5.1975 & 10.853 & 5.796 & 9.1975 & 2.1543 \\
\hline
\end{tabular}

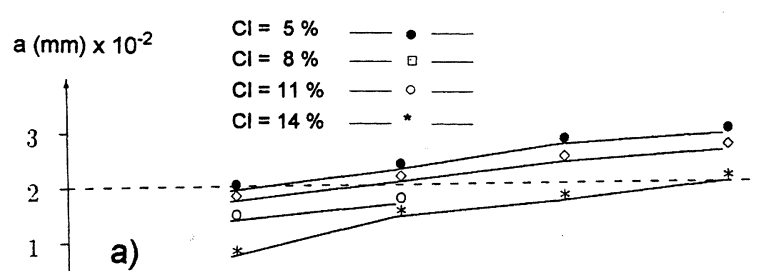

a)

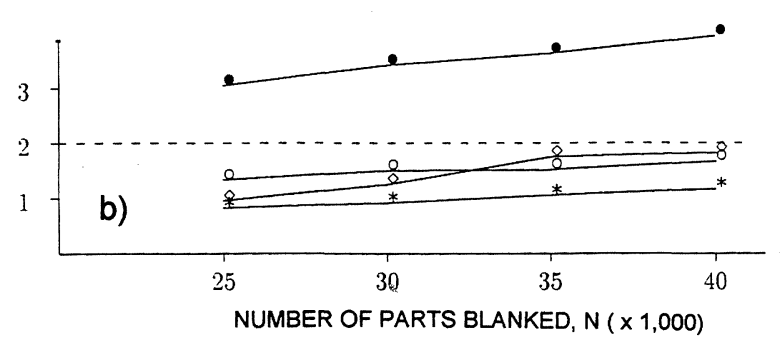

FIG. 8.- Magnitude $a$ versus number of strokes; a) diameter of punch $6 \mathrm{~mm}$; b) diameter of punch $8 \mathrm{~mm}$.

FIG. 8.- Valor de a frente al número de golpes; a) diámetro del punzón: $6 \mathrm{~mm}$; b) diámetro del punzón: $8 \mathrm{~mm}$.

If $N$ is the number of possible strokes between grindings the total number of blanks until complete tool failure is:

$$
\Sigma N_{\mathrm{i}}=n \times N_{1}=\frac{N_{1} \times A}{b}=N_{1} \frac{A}{\frac{2 S_{\mathrm{p}}}{a}}
$$

The maximum number of possible strokes, which it will give the economically accepted wear can be obtained differentiating with reference to $b$ and putting it equal to zero:

$$
\frac{d\left(\Sigma N_{\mathrm{i}}\right)}{d b}=\frac{d\left(\Sigma N_{\mathrm{i}}\right)}{d\left[\frac{2 S_{p}}{a}\right]}=0
$$

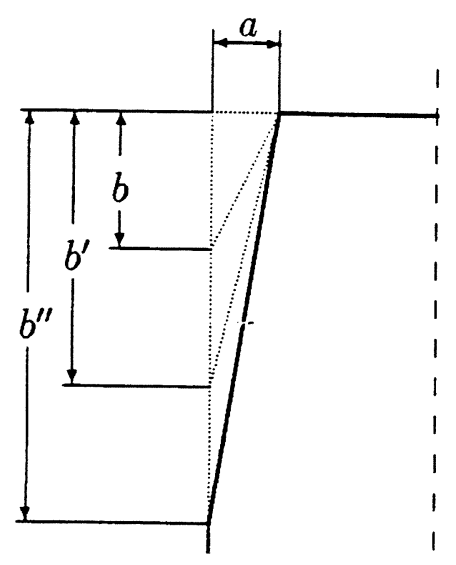

FIG. 9.- Variation of the triangle from wear section.

FIG. 9.- Variación triangular de la sección desgastada del punzón.

Operating:

$$
\frac{d\left(N_{\mathrm{i}}\right)}{d\left[\frac{2 S_{\mathrm{p}}}{a}\right]}=\frac{N_{\mathrm{i}}}{\frac{2 S_{\mathrm{p}}}{a}}
$$

This equation indicates that the $b$ value for the highest number of blanks can be determined from the curve that represents $N_{\mathrm{i}}$ versus $\left(2 S_{\mathrm{p}} / a\right)$ (Table III) and drawing the tangent to it that cuts the origin.

This graph can be observed in figure 10. From this curve the following values are obtained:

$$
b=295 \mu \mathrm{m}
$$

$N_{1}=24,100$ strokes (number of strokes between two consecutive grindings).

The results obtained by the present method are in good agreement with the previous experimental 
TABLE III.- Values of $N_{1}, S_{\mathrm{p}}$ and $2 S_{\mathrm{p}} / a$

TABLA III.- Valores de $\mathrm{N}_{1}, \mathrm{~S}_{\mathrm{p}}$ y $2 \mathrm{~S}_{\mathrm{p}} / \mathrm{a}$

\begin{tabular}{|c|l|l|}
\hline$N_{1}$ & $S_{\mathrm{p}}$ & $2 S_{\mathrm{p}} / a$ \\
\hline 15,000 & 1,416 & 141,6 \\
17,500 & 2,000 & 200 \\
20,000 & 2,432 & 243,2 \\
22,500 & 2,757 & 275,7 \\
25,000 & 3,081 & 308,1 \\
27,500 & 3,324 & 332,4 \\
30,000 & 3,600 & 360 \\
\hline
\end{tabular}

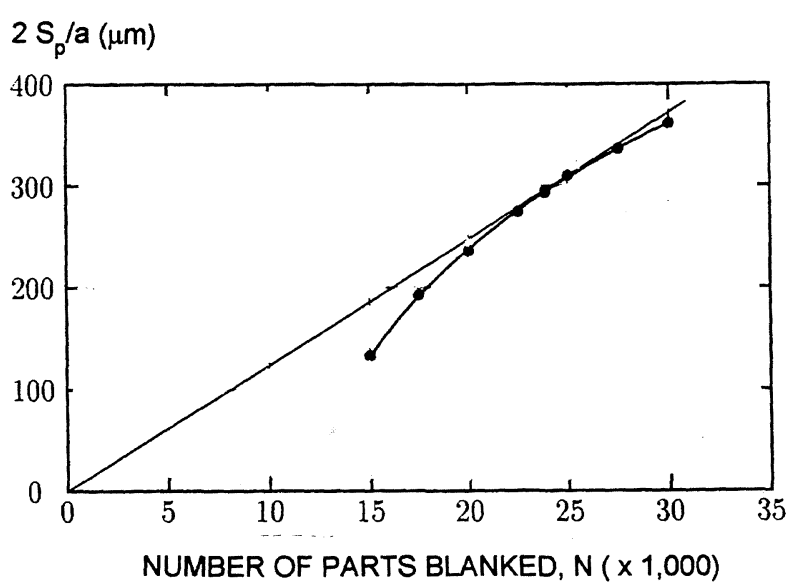

FIG. 10.- Relation between the value $b$ and the number of parts blanked.

FIG. 10.- Relación entre el valor de b y el número de piezas punzonadas.

and theoretical work. This value of $b$ coincides perfectly with manufacturers recommendations.

Now, the economically acceptable wear, $W_{\mathrm{e}}$, can be easily calculated:

$$
W_{\mathrm{e}}=S_{p_{\mathrm{e}}}=\frac{a \times b}{2}=\frac{20 \times 295}{2}=2,950 \mu \mathrm{m}^{2}
$$

\section{RELATION BETWEEN ECONOMICALLY ACCEPTED WEAR AND CLEARANCE}

In sheet forming processes by punching, the optimal conditions of the process are usually established by defining a value of clearance and economically accepted wear, according to the optimization criteria (12 and 13).

In order to facilitate the optimization of the conditions of the process, in the algorithms used, the dependent variable (cost, production, avails) will be expressed as a function of the parameters of the process (clearance, economically accepted wear).

For example, a common algorithm used in processes by punching can be seen in figure 11 . The problem would be to obtain an optimal clearance between cost of the tool (decreasing with the clearance) and defects of the blanked parts (increasing with the clearance).

Thus, in these processes, and as a function of the fundamental parameters of the process it is able to get the quantity of tool it could allow to wear before grinding it, maximizing the number of strokes. It will be important for the selection of the shearing conditions to know the relation between clearance and this value of wear that maximizes the tool life (14).

Therefore, the next target will be getting a relation between clearance and economically accepted wear. Following the same method described in this article, it is possible determine the economically accepted wear for each value of clearance, with a punch of $10 \mathrm{~mm}$ (Table IV) (6).

With clearance above a certain value (aproximately minimum wear clearance), the values of $W_{\mathrm{e}}$ are very small (Table IV), taking a limit value, since the grade of adaptation to use the tool is still aceptable, and, although the tool life falls, the costs of grinding decrease.

With the points of the table IV, it can realize an excellent regression, as:

$$
W_{\mathrm{e}}=u+v e^{\beta C l}
$$

whose results are shown on table V.

Therefore, this expresion relates the wear that the tool should have before being grinded with the used clearance.

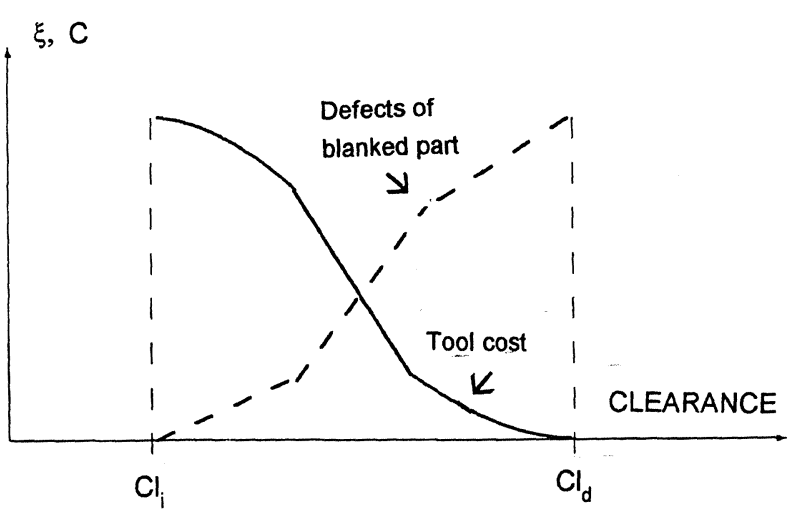

Fig. 11.- Tool cost and defects of blanked parts versus clearance.

FIG. 11.-Coste de la herramienta y defectos de las piezas punzonadas frente al juego de corte. 
TABLE IV.- Relation between $W_{\mathrm{e}}$ and $C l$ with diameter $10 \mathrm{~mm}$

TABLA IV.- Relación entre $\mathrm{W}_{\mathrm{e}} \mathrm{y} \mathrm{Cl}$ para un diámetro de $10 \mathrm{~mm}$

\begin{tabular}{|c|r|}
\hline$C l, \%$ & $W, \mu \mathrm{m}^{2}$ \\
\hline 9 & 4,230 \\
10 & 2,950 \\
11 & 2,330 \\
12 & 1,500 \\
13 & 830 \\
$14 \div 20$ & 500 \\
\hline
\end{tabular}

TABLE V.- Regression results

TABLA V.-Resultados de la regresión

\begin{tabular}{|c|c|c|c|}
\hline \multicolumn{4}{|c|}{ Coefficients } \\
\hline $\mathrm{u}$ & $\mathrm{v}$ & $\beta$ & $\mathbf{R}$ \\
\hline 337,78 & $194,887.56$ & 0.432 & $\mathbf{0 . 9 8 2 3 0 3}$ \\
\hline
\end{tabular}

\section{CONCLUSIONS}

In the present study, it has been stablished a simple and reliable criterion which, from an economical point of view, limits the tool life.

For this reason, it has perfomed a lot of tests, that have allowed to check certain hypothesis previously formulated, and to map this limit of wear with clearance, in order to facilitate the optimization of the process conditions.

Although tests and models have been developed just for a stainless steel family, the model (with the convenient corrections) could be extrapolated to other steel families commonly used in punching.

\section{Acknowledgements}

The authors thank the Comision Interministerial de Ciencia y Tecnología (CICYT) for the financial support to implement the investigation project TAP94-0886, by which this work was made possible.

\section{REFERENCES}

(1) TimmerbiL, F.W., Werkstattstech. u. Maschinenbau, (46) 1956: 58-66.

(2) PETER, H., Werkstattstech. Maschinenbau, (46) 1956: 5358.

(3) Buchmann, K., Werkstattstech. Maschinenbau., (53) 1963: 128-134.

(4) Sondershaus, E., Mitt. DFBO., (10) 1968: 142-156.

(5) ZIVANovic et al., Bänder, Bleche, Rohre, (10) 1981: 267270.

(6) Maeda, T. and Aoki, I., J. Fac. Eng. Univ. Tokyo (B)., Vol. XXXII, 1974: 443-475.

(7) AOKI, I., JSPT, 27, (300) 1986: 141-150.

(8) Georgiev, M. and Fuks-Rabinovich, G., Sci. Prod., 1987: 423-426.

(9) LeNIK, K., Sov. Forg. Sheet Met. Stamp. Techn., (3) 1988: 22-25.

(10) Maeda, T. and Aoki, I., J. Fac. Eng. Univ. Tokyo (B)., 32, (3) 1974: 443-445.

(11) Faura, F., Sebastian, M.A., Dominguez, M. y Cervantes, J.F. Análisis del desgaste en herramientas de corte por punzonado. AEIM. Madrid. I Congreso Iberoamericano de Ingeniería Mecánica, Vol. 3, 1993: 267.

(12) Faura, F., Sebastian, M.A., Dominguez, M. y Nacher, A., Def. Metálica, (210) 1993: 27-38.

(13) Dominguez, M., Espinosa, M., Sebastian, M.A. and FAURA, F., Basis for the optimitation of metal forming process in flexible manufacturing systems environment. Intern. Conf. on CAD/CAM, Robotics and Factories of the future. St. Petersburg, May 17-19, 1993.

(14) Faura, F., Lopez, J., Sebastian, M.A. and Luis, C., $A d v$. Technol. Plast., Vol. 2, 1996: 655-664. 